\title{
Pengaruh Jarak Tanam dan Takaran Pupuk Kandang Sapi terhadap Pertumbuhan dan Hasil Tanaman Buncis (Phaseolus vulgaris L.)
}

Reni Marianti Missa ${ }^{a}$

${ }^{a}$ Fakultas Pertanian, Universitas Timor, Kefamenanu, TTU - NTT, Indonesia.

\section{Article Info}

Article history:

Received 31 Mei 2018

Received in revised form 19 Juni 2018

Accepted 4 Juli 2018

DOI:

https://doi.org/10.32938/sc.v3i03.313

Keywords:

Jarak Tanam

Pupuk

Takaran

\section{Abstrak}

Penelitian ini bertujuan untuk mengetahui pengaruh jarak tanam dan takaran pupuk kandang terhadap pertumbuhan dan hasil tanaman buncis serta mengetahui takaran pupuk kandang dan jarak tanam yang tepat untuk pertumbuhan dan hasil buncis yang optimum. Rancangan yang digunakan adalah Rancangan Acak Kelompok (RAK) faktorial 3 × 3 yang diulang tiga kali. Faktor pertama adalah jarak tanam yang terdiri dari tiga aras yaitu $20 \mathrm{~cm}$ x $40 \mathrm{~cm}, 20 \times 50 \mathrm{~cm}$ dan $20 \mathrm{~cm} \times 60 \mathrm{~cm}$. faktor kedua adalah takaran pupuk kandang terdiri dari tiga aras yaitu 5 t/ha, 10 t/ha dan 15 t/ha. Parameter yang diamati meliputi suhu tanah, kadar lengas tanah, tinggi tanaman, diameter batang, jumlah daun, jumlah polong per tanaman, berat polong per tanaman, jumlah hasil polong per petak, berat basah berangkasan, berat kering berangkasan, berat basah akar, berat kering akar, berat basah batang, berat kering batang. Hasil penelitian menunjukkan bahwa interaksi antara jarak tanam dan takaran pupuk kandang sapi terjadi pada parameter berat basah akar dan jumlah polong per petak setiap kali panen. Takaran pupuk kandang berpengaruh nyata pada parameter kadar lengas 60 HST dan polong buncis, sedangkan jarak tanam tidak berpengaruh nyata terhadap semua parameter. Perlakuan jarak tanam $20 \mathrm{~cm}$ x $40 \mathrm{~cm}$ dengan takaran pupuk 10 t/ha sudah cukup meningkatkan hasil tanaman buncis berat polong per petak (4,25 t/ha) lebih tinggi dibanding perlakuan lainnya.

\section{Pendahuluan}

Buncis (Phaseolus vulgaris L.) merupakan salah satu jenis tanaman sayuran polong yang memiliki banyak kegunaan. Polong buncis, sebagai bahan sayuran dapat dikonsumsi dalam keadaan muda atau dikonsumsi bijinya. Buncis bukan tanaman asli Indonesia, tetapi berasal dari Meksiko Selatan dan Amerika Tengah. Buncis yang dibudidayakan oleh masyarakat di Indonesia memiliki banyak jenis. Tanaman buncis secara garis besar dibagi dalam dua tipe yaitu buncis tipe membelit atau merambat dan buncis tipe tegak atau tidak merambat (Cahyono, 2007).

Buncis merupakan sumber protein, vitamin dan mineral yang penting dan mengandung zat-zat lain yang berkhasiat untuk obat dalam berbagai macam penyakit. Gum dan pektin yang terkandung dapat menurunkan kadar gula darah, sedangkan lingnim berkhasiat untuk mencegah kanker usus besar dan kanker payudara. Serat kadar dalam polong buncis sangat berguna untuk melancarkan pencernaan sehingga dapat mengeluarkan zat-zat racun dari tubuh (Cahyono, 2007)

Menurut Rubatzky \& Yamaguchi, (2012), peningkatan produksi buncis mempunyai arti penting dalam menunjang peningkatan gizi masyarakat, sekaligus berdasarkan tipe pertumbuhannya dan kebiasaan panennya, yaitu buncis tipe tegak berdaya guna bagi usaha mempertahankan kesuburan dan produktivitas tanah. Kacang buncis merupakan salah satu sumber protein nabati yang murah dan mudah dikembangkan.

Jarak tanam yang rapat akan mengganggu penyerapan zat hara oleh tanaman, karena akar tanaman yang satu akan masuk ke dalam perakaran tanaman lainnya sehingga saling berebut dalam penyerapan zat hara. Penanaman dengan jarak tanam yang terlalu lebar juga kurang menguntungkan karena penggunaan lahan tidak efisien. Tanaman buncis yang memiliki tipe pertumbuhan tegak, jarak tanam $20 \times 50 \mathrm{~cm}$ dapat menghasilkan buah yang berukuran besar (Wirakusumah, 1994)

Usaha untuk memperbaiki pertumbuhan dan meningkatkan hasil buncis dapat dilakukan dengan penggunaan varietas unggul dan pemupukan Pemupukan diusahakan agar unsur hara yang dibutuhkan tanaman tersedia dalam jumlah yang cukup sesuai dengan kebutuhan tanaman. Berbagai hasil penelitian membuktikan bahwa pupuk kandang dapat meningkatkan pertumbuhan dan hasi tanaman seperti Naimnule, (2016) melaporkan bahwa hasil tertinggi kacang hijau diperoleh dari pemberian pupuk kandang sapi 5 t/ha dibanding yang tidak diberikan pupuk

Pupuk kandang dapat mengurangi efisiensi penggunaan pupuk kimia akan menyumbangkan unsur hara bagi tanaman serta meningkatkan serapan unsu hara oleh tanaman, di samping itu pemberian pupuk kandang juga dapat memperbaiki sifat fisika tanah, yaitu kapasitas tanah menahan air, kerapatan massa tanah, dan porositas total, memperbaiki stabilitas agregat tanah dan meningkatkan kandungan humus tanah suatu kondisi yang dikehendaki oleh tanaman sayur-sayuran (Winarno \& Winarto, 1992).

Berdasarkan uraian di atas perlu usaha untuk meningkatkan hasil pada tanaman buncis, yaitu dengan perlakuan pemupukan dalam budidaya tanaman buncis. Penelitian tentang pengaruh jarak tanam dan takaran pupuk kandang sap terhadap dan hasil tanaman buncis, sangat diperlukan untuk pengembangan usaha budidaya buncis.

\section{Metode}

Penelitian ini dilaksanakan pada bulan April - Juni 2017, di Desa Lapeom, Kecamatan Insana Barat, Kabupaten Timor Tengah Utara, Provinsi Nusa Tenggara Timur. Rancangan yang digunakan dalam penelitian ini adalah Rancangan Acak Kelompok (RAK) faktorial. Faktor pertama adalah jarak tanam (J) yang terdiri atas 3 aras perlakuan yaitu : $20 \times 40 \mathrm{~cm}\left(\mathrm{j}_{1}\right), 20 \times 50 \mathrm{~cm}\left(\mathrm{j}_{2}\right)$ dan $20 \times 60 \mathrm{~cm}\left(\mathrm{j}_{3}\right)$. Faktor kedua adalah takaran pupuk kandang $(\mathrm{T})$ yang terdiri atas aras 3 perlakuan yaitu: $5 \mathrm{t} / \mathrm{ha}\left(\mathrm{t}_{1}\right), 10 \mathrm{t} / \mathrm{ha}\left(\mathrm{t}_{2}\right)$ dan $15 \mathrm{t} / \mathrm{ha}\left(\mathrm{t}_{3}\right)$. Kombinasi perlakuannya adalah: $\mathrm{j}_{1} \mathrm{t}_{1}, \mathrm{j}_{1} \mathrm{t}_{2}, \mathrm{j}_{1} \mathrm{t}_{3}, \mathrm{j}_{2} \mathrm{t}_{1}, \mathrm{j}_{2} \mathrm{t}_{2}, \mathrm{j}_{2} \mathrm{t}_{3}, \mathrm{j}_{3} \mathrm{t}_{1}, \mathrm{j}_{3} \mathrm{t}_{2}$, dan $\mathrm{j}_{3} \mathrm{t}_{3}$ yang di ulang $3 \mathrm{kal}$ sehingga seluruhnya terdapat 27 unit petak percobaan.
Pelaksanaan percobaan yaitu dengan persiapan benih, pengolahan tanah, pemberian pupuk kandang, penanaman, pemeliharaan, penyiraman, pemberian ajir penyulaman, penyiangan, panen. Pengamatan meliputi suhu tanah $\left({ }^{\circ} \mathrm{C}\right)$, kadar lengas tanah $(\%)$, tinggi tanaman $(\mathrm{cm})$, diameter batang $(\mathrm{mm})$, jumlah daun, jumlah polong per tanaman (buah), berat polong per tanaman (g), jumlah polong per petak (buah), berat basah berangkasan (g), berat kering berangkasan $(\mathrm{g})$, dan indeks panen (\%). Semua data yang dikumpulkan dianalisis dengan menggunakan analisa sidik ragam, Rancangan Acak Kelompok (RAK), untuk mengetahui ada tidaknya pengaruh antara faktor perlakuan. Jika terdapat beda nyata di antara rerata perlakuan selanjutnya diuji dengan menggunakan DMRT (Duncan multiple range test). Data diuji lanjut pada tingkat nyata $(\alpha) 5 \%$ menuru uji DMRT untuk mengetahui adanya interaksi antara jarak tanam dan Takaran pupuk kandang sapi. Analisis data dilakukan sesuai petunjuk Gomez \& Gomez, (1984).

\section{Hasil dan Pembahasan}

\subsection{Suhu Tanah}

Hasil analisis menunjukkan bahwa jarak tanam dan takaran pupuk kandang tidak berpengaruh nyata terhadap suhu tanah pada setiap waktu pengamatan serta tidak terjadi interaksi antar perlakuan. Pengaruh utama perlakuan jarak tanam tidak berpengaruh nyata pada setiap waktu pengamatan, tetapi suhu tanah tertinggi terjadi pada petak yang ditanami buncis dengan jarak $20 \mathrm{~cm} \times 60 \mathrm{~cm}$. Pengaruh utama perlakuan takaran pupuk kandang tidak berpengaruh nyata terhadap suhu tanah pada setiap waktu pengamatan. Pada pengamatan 45 HST dan 60 HST suhu tanah tertinggi terdapat pada petak yang diberikan pupuk dengan takaran $5 \mathrm{t} / \mathrm{ha}$. (Tabel 1.).

Tabel 1. Suhu Tanah

\begin{tabular}{cccccc}
\hline \multirow{2}{*}{ Waktu } & \multirow{2}{*}{ Jarak Tanam } & \multicolumn{3}{c}{ Takaran Pupuk Kandang } & \multirow{2}{*}{ Rerata } \\
\cline { 2 - 5 } & & $5 \mathrm{t} / \mathrm{ha}$ & $10 \mathrm{t} / \mathrm{ha}$ & $15 \mathrm{t} / \mathrm{ha}$ & \\
\hline \multirow{3}{*}{$1 \mathrm{HST}$} & $20 \times 40$ & 28,85 & 32,02 & 31,94 & $30,94 \mathrm{a}$ \\
& $20 \times 50$ & 31,41 & 30,57 & 33,03 & $31,67 \mathrm{a}$ \\
& $20 \times 60$ & 32,46 & 32,81 & 32,24 & $32,50 \mathrm{a}$ \\
\cline { 2 - 5 } & Rerata & $30,91 \mathrm{a}$ & $31,80 \mathrm{a}$ & $32,41 \mathrm{a}$ & $(-)$ \\
\hline \multirow{3}{*}{45 HST } & $20 \times 40$ & 30,52 & 27,79 & 29,20 & $29,17 \mathrm{a}$ \\
& $20 \times 50$ & 30,22 & 29,35 & 30,02 & $29,86 \mathrm{a}$ \\
& $20 \times 60$ & 30,00 & 29,78 & 30,56 & $30,11 \mathrm{a}$ \\
\hline \multirow{3}{*}{$60 \mathrm{HST}$} & Rerata & $30,25 \mathrm{a}$ & $28,97 \mathrm{a}$ & $29,92 \mathrm{a}$ & $(-)$ \\
& $20 \times 40$ & 26,00 & 25,29 & 25,81 & $25,70 \mathrm{a}$ \\
& $20 \times 50$ & 25,57 & 25,98 & 26,76 & $26,10 \mathrm{a}$ \\
& $20 \times 60$ & 26,76 & 26,13 & 25,64 & $26,18 \mathrm{a}$ \\
\hline
\end{tabular}

Keterangan: Angka pada kolom dan baris diikuti huruf sama menunjukkan tidak berbeda pada tingkat nyata $(\alpha) 5 \%$ menurut uji DMRT; (-): Tidak terjadi interaksi antar faktor

\subsection{Kadar Lengas Tanah}

Hasil sidik ragam menunjukkan bahwa tidak terjadi interaksi antar perlakuan jarak tanam dengan takaran pupuk kandang terhadap kadar lengas tanah pada setiap waktu pengamatan. Perlakuan utama jarak tanam tidak berpengaruh nyata pada setiap waktu pengamatan tetapi kadar lengas tanah tertinggi pada petak yang jarak tanam $20 \mathrm{~cm}$ x $60 \mathrm{~cm}$ memberikan kadar lengas tanah tertinggi $(33,94 \%)$. Perlakuan utama takaran pupuk kandang tidak berpengaruh nyata pada setiap waktu pengamatan tetapi pada pengamatan 60 HST kadar lengas tanah tertinggi pada petak yang diberikan $10 \mathrm{t} / \mathrm{h}$. 
Tabel 2. Kadar Lengas Tanah (\%)

\begin{tabular}{cccccc}
\hline \multirow{2}{*}{ Waktu } & Jarak & \multicolumn{3}{c}{ Takaran Pupuk Kandang } & \multirow{2}{*}{ Rerata } \\
\cline { 3 - 5 } & Tanam & $5 \mathrm{t} / \mathrm{ha}$ & $10 \mathrm{t} / \mathrm{ha}$ & $15 \mathrm{t} / \mathrm{ha}$ & \\
\hline \multirow{4}{*}{ HST } & $20 \times 40$ & 34,17 & 30,17 & 29,43 & $31,25 \mathrm{a}$ \\
& $20 \times 50$ & 31,43 & 7,57 & 25,03 & $28,01 \mathrm{a}$ \\
& $20 \times 60$ & 30,19 & 34,30 & 37,34 & $33,94 \mathrm{a}$ \\
\hline \multirow{4}{*}{45 HST } & Rerata & $31,93 \mathrm{a}$ & $30,68 \mathrm{a}$ & $30,06 \mathrm{a}$ & $(-)$ \\
\hline & $20 \times 40$ & 29,18 & 37,54 & 26,88 & $31,2 \mathrm{a}$ \\
& $20 \times 50$ & 31,19 & 27,93 & 28,32 & $29,14 \mathrm{a}$ \\
& $20 \times 60$ & 27,06 & 20,18 & 34,54 & $27,26 \mathrm{a}$ \\
\hline \multirow{4}{*}{60 HST } & Rerata & $29,14 \mathrm{a}$ & $28,55 \mathrm{a}$ & $29,91 \mathrm{a}$ & $(-)$ \\
& $20 \times 40$ & 36,51 & 28,35 & 29,18 & $31,34 \mathrm{a}$ \\
& $20 \times 50$ & 29,27 & 34,29 & 34,26 & $32,60 \mathrm{a}$ \\
& $20 \times 60$ & 35,19 & 27,38 & 29,32 & $30,63 \mathrm{a}$ \\
\hline & Rerata & $33,65 \mathrm{a}$ & $36,00 \mathrm{a}$ & $30,92 \mathrm{a}$ & $(-)$ \\
\hline
\end{tabular}

Keterangan: Angka pada kolom dan baris diikuti huruf sama menunjukkan tidak berbeda pada tingkat nyata ( $\alpha$ ) $5 \%$ menurut uji DMRT; (-): Tidak terjadi interaksi antar faktor.

\subsection{Tinggi Tanaman}

Hasil sidik ragam menunjukkan bahwa tidak terjadi interaksi antar perlakuan jarak tanam dengan takaran pupuk kandang terhadap tinggi tanaman pada setiap waktu pengamatan. Perlakuan utama jarak tanam tidak berpengaruh nyata pada. setiap waktu pengamatan petak dengan jarak tanam $20 \mathrm{~cm}$ x $50 \mathrm{~cm}$ menghasilkan tanaman tertinggi.

Perlakuan utama takaran pupuk kandang tidak berpengaruh nyata tetapi pada pengamatan 28 dan $42 \mathrm{HST}$, pada petak yang diberi perlakuan $10 \mathrm{t} / \mathrm{ha}$ terdapat tanaman yang paling tinggi $(20,76 \mathrm{~cm}$ dan $101,88 \mathrm{~cm}$ (Tabel 3.$)$.

Tabel 3. Tinggi Tanaman

\begin{tabular}{cccccc}
\hline \multirow{2}{*}{ Waktu } & Jarak & \multicolumn{3}{c}{ Takaran Pupuk Kandang } & \multirow{2}{*}{ Rerata } \\
\cline { 3 - 5 } & Tanam & $5 \mathrm{t} / \mathrm{h} a$ & $10 \mathrm{t} / \mathrm{h} a$ & $15 \mathrm{t} / \mathrm{ha}$ & \\
\hline \multirow{3}{*}{$14 \mathrm{HST}$} & $20 \times 40$ & 15,50 & 15,16 & 12,20 & $13,62 \mathrm{a}$ \\
& $20 \times 50$ & 12,30 & 13,66 & 12,89 & $12,95 \mathrm{a}$ \\
& $20 \times 60$ & 13,14 & 13,86 & 12,45 & $13,15 \mathrm{a}$ \\
\hline \multirow{3}{*}{$2 \mathrm{HST}$} & Rerata & $13,63 \mathrm{a}$ & $12,78 \mathrm{a}$ & $12,25 \mathrm{a}$ & $(-)$ \\
& $20 \times 40$ & 18,6 & 19,26 & 18,83 & $18,90 \mathrm{a}$ \\
& $20 \times 50$ & 17,56 & 20,46 & 18,53 & $18,85 \mathrm{a}$ \\
& $20 \times 60$ & 18,94 & 20,16 & 18,76 & $19,29 \mathrm{a}$ \\
\hline \multirow{3}{*}{ 42 HST } & Rerata & $18,36 \mathrm{a}$ & $19,96 \mathrm{a}$ & $18,71 \mathrm{a}$ & $(-)$ \\
& $20 \times 40$ & 89,33 & 97,53 & 106,00 & $97,62 \mathrm{a}$ \\
& $20 \times 50$ & 96,67 & 108,13 & 96,67 & $103,48 \mathrm{a}$ \\
& $20 \times 60$ & 109,67 & 100,00 & 100,93 & $100,53 \mathrm{a}$ \\
\hline & Rerata & $98,55 \mathrm{a}$ & $101,88 \mathrm{a}$ & $101,20 \mathrm{a}$ & $(-)$ \\
\hline
\end{tabular}

Keterangan: Angka pada kolom dan baris diikuti huruf sama menunjukkan tidak berbeda pada tingkat nyata $(\alpha) 5 \%$ menurut uji DMRT; (-): Tidak terjadi interaksi antar faktor.

\subsection{Jumlah Daun}

Hasil sidik ragam menunjukkan bahwa tidak terjadi interaksi antar perlakuan jarak tanam dengan takaran pupuk kandang terhadap jumlah daun pada setiap waktu pengamatan. Perlakuan utama tidak berpengaruh nyata pada setiap waktu pengamatan tetapi pada petak yang diberi takaran pupuk kandang $10 \mathrm{t} / \mathrm{ha}$ menghasilkan tanaman dengan jumlah daun terbanyak pada pengamatan 45 dan 60 HST. Perlakuan utama jarak tanam tidak berpengaruh nyata pada setiap waktu pengamatan tetapi pada pengamatan 45 dan 60 HST tanaman menghasilkan jumlah daun terbanyak dengan jarak tanam $20 \mathrm{~cm} \times 60 \mathrm{~cm}$ (Tabel 4.).

Tabel 4. Jumlah Daun.

\begin{tabular}{cclllc}
\hline \multirow{2}{*}{ Waktu } & \multirow{2}{*}{ Jarak Tanam } & \multicolumn{3}{c}{ Takaran Pupuk Kandang } & \multirow{2}{*}{ Rerata } \\
\cline { 2 - 5 } & & $5 \mathrm{t} / \mathrm{ha}$ & $10 \mathrm{t} / \mathrm{ha}$ & $15 \mathrm{t} / \mathrm{ha}$ & \\
\hline \multirow{3}{*}{$14 \mathrm{HST}$} & $20 \times 40$ & 8,66 & 8,40 & 8,0 & $8,35 \mathrm{a}$ \\
& $20 \times 50$ & 8,40 & 9,33 & 8,6 & $8,88 \mathrm{a}$ \\
& $20 \times 60$ & 8,40 & 9,00 & 8,6 & $8,66 \mathrm{a}$ \\
\cline { 2 - 5 } $28 \mathrm{HST}$ & Rerata & $8,48 \mathrm{a}$ & $8,91 \mathrm{a}$ & $8,51 \mathrm{a}$ & $(-)$ \\
\hline \multirow{3}{*}{$42 \mathrm{HST}$} & $20 \times 40$ & 23,86 & 25,46 & 25,6 & $24,97 \mathrm{a}$ \\
& $20 \times 50$ & 23,06 & 26,53 & 25,86 & $25,15 \mathrm{a}$ \\
& $20 \times 60$ & 27,06 & 27,93 & 23,6 & $26,20 \mathrm{a}$ \\
\cline { 2 - 5 } & Rerata & $24,66 \mathrm{a}$ & $26,64 \mathrm{a}$ & $25,02 \mathrm{a}$ & $(-)$ \\
\hline & $20 \times 40$ & 27,0 & 26,06 & 24,33 & $25,80 \mathrm{a}$ \\
& $20 \times 50$ & 27,8 & 28,13 & 26,26 & $27,40 \mathrm{a}$ \\
& $20 \times 60$ & 26,0 & 29,26 & 26,47 & $27,44 \mathrm{a}$ \\
\hline
\end{tabular}

Keterangan: Angka pada kolom dan baris diikuti huruf sama menunjukkan tidak berbeda pada tingkat nyata $(\alpha) 5 \%$ menurut uji DMRT; (-): Tidak terjadi interaksi antar faktor.

\subsection{Diameter Batang}

Hasil sidik ragam menunjukkan bahwa tidak terjadi interaksi antar perlakuan jarak tanam dengan takaran pupuk kandang terhadap diameter batang pada setiap waktu pengamatan. Perlakuan utama takaran pupuk kandang tidak berpengaruh nyata pada setiap waktu pengamatan, tetapi petak yang diberi takaran $15 \mathrm{t} / \mathrm{ha}$ menghasilkan tanaman dengan diameter batang terbesar pada pengamatan 45 dan 60 HST. Perlakuan utama jarak tanam tidak berpengaruh nyata pada setiap waktu pengamatan, tetapi pada pengamatan 45 dan 60 HST tanaman menghasilkan diameter batang terbesar dengan jarak tanam $20 \mathrm{~cm}$ x 50 $\mathrm{cm}$.

Tabel 5. Diameter Batang (cm).

\begin{tabular}{cccccc}
\hline \multirow{2}{*}{ Waktu } & \multirow{2}{*}{ Jarak Tanam } & \multicolumn{3}{c}{ Takaran Pupuk Kandang } & \multirow{2}{*}{ Rerata } \\
\cline { 2 - 5 } & & $5 \mathrm{t} / \mathrm{ha}$ & $10 \mathrm{t} / \mathrm{ha}$ & $15 \mathrm{t} / \mathrm{ha}$ & \\
\hline \multirow{3}{*}{14 HST } & $20 \times 40$ & 0,16 & 0,93 & 0,60 & $1,23 \mathrm{a}$ \\
& $20 \times 50$ & 0,80 & 0,66 & 0,80 & $0,75 \mathrm{a}$ \\
& $20 \times 60$ & 1,00 & 0,90 & 0,83 & $0,91 \mathrm{a}$ \\
\cline { 2 - 5 } $45 \mathrm{HST}$ & Rerata & $1,32 \mathrm{a}$ & $0,83 \mathrm{a}$ & $0,74 \mathrm{a}$ & $(-)$ \\
\hline \multirow{3}{*}{$60 \mathrm{HST}$} & $20 \times 40$ & 1,16 & 0,93 & 1,43 & $1,17 \mathrm{a}$ \\
& $20 \times 50$ & 1,23 & 1,40 & 1,63 & $1,42 \mathrm{a}$ \\
& $20 \times 60$ & 1,36 & 1,13 & 1,36 & $1,28 \mathrm{a}$ \\
\hline & $20 \times 40$ & 1,43 & 1,56 & 1,50 & $1,50 \mathrm{a}$ \\
& $20 \times 50$ & 1,60 & 1,43 & 1,70 & $1,57 \mathrm{a}$ \\
& $20 \times 60$ & 1,96 & 1,43 & 1,50 & $1,46 \mathrm{a}$ \\
\hline & Rerata & $1,50 \mathrm{a}$ & $1,47 \mathrm{a}$ & $1,56 \mathrm{a}$ & $(-)$ \\
\hline
\end{tabular}

Keterangan: Angka pada kolom dan baris diikuti huruf sama menunjukkan tidak berbeda pada tingkat nyata $(\alpha) 5 \%$ menurut uji DMRT; (-): Tidak terjadi interaksi antar faktor.

\subsection{Berat Basah Akar}

Hasil sidik ragam menunjukkan bahwa terjadi interaksi antar perlakuan jarak tanam dengan takaran pupuk kandang terhadap berat basah akar pada setiap waktu pengamatan. Perlakuan utama jarak tanaman dan takaran pupuk kandang tidak berpengaruh nyata. Tanaman yang diberi takaran pupuk kandang $10 \mathrm{t} / \mathrm{ha}$ dengan jarak tanam $20 \mathrm{~cm}$ x $60 \mathrm{~cm}$ menghasilkan berat basah akar paling berat (Tabel 6.).

Tabel 6. Berat Basah Akar

\begin{tabular}{ccccc}
\hline Jarak & \multicolumn{3}{c}{ Takaran Pupuk Kandang } & \multirow{2}{*}{ Rerata } \\
\cline { 2 - 4 } Tanam & $5 \mathrm{t} / \mathrm{ha}$ & $10 \mathrm{t} / \mathrm{ha}$ & $15 \mathrm{t} / \mathrm{ha}$ & \\
\hline $20 \times 40$ & $3,6 \mathrm{ab}$ & $2,75 \mathrm{ab}$ & $3,00 \mathrm{ab}$ & $3,31 \mathrm{a}$ \\
$20 \times 50$ & $4,1 \mathrm{ab}$ & $2,60 \mathrm{ab}$ & $4,20 \mathrm{a}$ & $3,63 \mathrm{a}$ \\
$20 \times 60$ & $3,8 \mathrm{ab}$ & $3,17 \mathrm{ab}$ & $1,96 \mathrm{~b}$ & $3,43 \mathrm{a}$ \\
\hline Rerata & $3,83 \mathrm{a}$ & $3,48 \mathrm{a}$ & $3,05 \mathrm{a}$ & $(+)$ \\
\hline
\end{tabular}

Keterangan: Angka pada kolom dan baris diikuti huruf sama menunjukkan tidak berbeda pada tingkat nyata $(\alpha) 5 \%$ menurut uji DMRT; $(+)$ : Terjadi interaksi antar faktor.

\subsection{Berat Kering Akar}

Hasil sidik ragam menunjukkan bahwa tidak terjadi interaksi antar perlakuan jarak tanam dengan takaran pupuk kandang terhadap berat kering akar pada pengamatan 74 HST. Perlakuan utama takaran pupuk kandang tidak berpengaruh nyata, tetapi petak yang diberi takaran 10 t/ha menghasilkan tanaman berat kering akar paling berat. Perlakuan utama jarak tanam tidak berpengaruh nyata, tetapi tanaman menghasilkan berat kering akar paling berat dengan jarak tanam $20 \mathrm{~cm} \times 50 \mathrm{~cm}$ (Tabel 7.).

Tabel 7. Berat Kering akar

\begin{tabular}{ccllll}
\hline \multirow{2}{*}{ Jarak } & \multirow{2}{*}{ Jarak Tanam } & \multicolumn{3}{c}{ Takaran Pupuk Kandang } & \multirow{2}{*}{ Rerata } \\
\cline { 3 - 5 } Tanam & & 5 t/ha & 10 t/ha & 15 t/han & \\
\hline $20 \times 40$ & $20 \times 40$ & 0,96 & 0,9 & 0,76 & $0,87 \mathrm{a}$ \\
$20 \times 50$ & $20 \times 50$ & 1,13 & $1,00^{\prime}$ & 1,00 & $1,94 \mathrm{a}$ \\
$20 \times 60$ & $20 \times 60$ & 0,9 & 1,00 & 1,03 & $0,97 \mathrm{a}$ \\
\hline Rerata & Rerata & $0,87 \mathrm{a}$ & $0,96 \mathrm{a}$ & $0,93 \mathrm{a}$ & $(-)$
\end{tabular}

Keterangan: Angka pada kolom dan baris diikuti huruf sama menunjukkan tidak berbeda pada tingkat nyata $(\alpha) 5 \%$ menurut uji DMRT; (-): Tidak terjadi interaksi antar faktor.

\subsection{Berat Basah Berangkasan}

Hasil sidik ragam menunjukkan bahwa tidak terjadi interaksi antar perlakuan jarak tanam dengan takaran pupuk kandang terhadap berat basah berangkasan pada pengamatan 74 HST. Perlakuan utama takaran pupuk kandang tidak berpengaruh nyata tetapi petak yang diberi takaran $10 \mathrm{t} / \mathrm{ha}$ menghasilkan tanaman dengan berat basah berangkasan paling berat. Perlakuan utama jarak tanam tidak berpengaruh nyata, tetapi tanaman menghasilkan berat basah berangkasan paling berat dengan jarak tanam $20 \mathrm{~cm}$ x $60 \mathrm{~cm}$.

Tabel 8. Berat Basah Berangkasan (g)

\begin{tabular}{cccccc}
\hline Waktu & Jarak & \multicolumn{3}{c}{ Takaran Pupuk Kandang } & \multirow{2}{*}{ Rerata } \\
\cline { 3 - 5 } Panen & Tanam & 5 t/ha & 10 t/ha & 15 t/ha & \\
\hline \multirow{2}{*}{74 HST } & $20 \times 40$ & 14,30 & 15,12 & 12,57 & $18,60 \mathrm{a}$ \\
& $20 \times 50$ & 11,57 & 10,43 & 9,56 & $13,57 \mathrm{a}$ \\
& $20 \times 60$ & 13,40 & 18,30 & 9,37 & $10,50 \mathrm{a}$ \\
\hline Rerata & Rerata & $13,09 \mathrm{a}$ & $12,19 \mathrm{a}$ & $10,48 \mathrm{a}$ & $(-)$ \\
\hline
\end{tabular}

Keterangan: Angka pada kolom dan baris diikuti huruf sama menunjukkan tidak berbeda pada tingkat nyata $(\alpha) 5 \%$ menurut uji DMRT; (-): Tidak terjadi interaksi antar faktor. 


\subsection{Berat Kering Berangkasan}

Hasil sidik ragam menunjukkan bahwa tidak terjadi interaksi antar perlakuan, jarak tanam dengan takaran pupuk kandang terhadap berat kering berangkasan pada pengamatan 74 HST. Perlakuan utama takaran pupuk kandang tidak berpengaruh nyata, tetapi petak yang diberi takaran $10 \mathrm{t} / \mathrm{ha}$ menghasilkan berat kering berangkasan yang paling berat. Perlakuan utama jarak tanam tidak berpengaruh nyata, tetapi tanaman menghasilkan berat berangkasan paling berat dengan jarak tanam $20 \mathrm{~cm}$ x $60 \mathrm{~cm}$.

Tabel 9. Berat kering berangkasan $(\mathrm{g})$

\begin{tabular}{cccccc}
\hline Waktu & Jarak & \multicolumn{3}{c}{ Takaran Pupuk Kandang } & \multirow{2}{*}{ Rerata } \\
\cline { 3 - 5 } Panen & Tanam & $5 \mathrm{t} / \mathrm{ha}$ & $10 \mathrm{t} / \mathrm{ha}$ & $15 \mathrm{t} / \mathrm{ha}$ & \\
\hline \multirow{3}{*}{ 74 HST } & $20 \times 40$ & 3,33 & 3,3 & 2,76 & $3,13 \mathrm{a}$ \\
& $20 \times 50$ & 2,93 & 3,26 & 2,9 & $3,23 \mathrm{a}$ \\
& $20 \times 60$ & 3,4 & 4,03 & 3,56 & $3,66 \mathrm{a}$ \\
\cline { 2 - 5 } & Rerata & $3,22 \mathrm{a}$ & $3,53 \mathrm{a}$ & $3,07 \mathrm{a}$ & $(-)$ \\
\hline
\end{tabular}

Keterangan: Angka pada kolom dan baris diikuti huruf sama menunjukkan tidak berbeda pada tingkat nyata $(\alpha) 5 \%$ menurut uji DMRT; (-): Tidak terjadi interaks antar faktor.

\subsection{Jumlah Polong Per Tanaman}

Hasil sidik ragam menunjukkan bahwa tidak terjadi interaksi antara perlakuan pupuk kandang dengan jarak tanam terhadap jumlah polong per tanaman pada setiap waktu pengamatan. Perlakuan utama jarak tanam tidak berpengaruh nyata pada setiap waktu pengamatan, tetapi penanaman dengan jarak $20 \mathrm{~cm}$ x $50 \mathrm{~cm}$ menghasilkan jumlah polong per tanaman paling banyak. Perlakuan utama takaran pupuk kandang tidak berpengaruh nyata terhadap jumlah polong per tanaman pada setiap waktu pengamatan. Pada pengamatan 60 HST jumlah polong terbanyak $(8,26)$ terdapat tanaman yang diberi pupuk dengan takaran $15 \mathrm{t} /$ ha, sedangkan pada pengamatan 74 HST terdapat pada tanaman yang diberi pupuk dengan takaran $5 \mathrm{t} / \mathrm{ha}$.

Tabel 10. Jumlah Polong Per Tanaman

\begin{tabular}{cccllc}
\hline \multirow{2}{*}{ Waktu Panen } & Jarak & \multicolumn{3}{c}{ Takaran Pupuk Kandang } & \multirow{2}{*}{ Rerata } \\
\cline { 3 - 5 } & Tanam & $5 \mathrm{t} / \mathrm{ha}$ & $10 \mathrm{t} / \mathrm{ha}$ & $15 \mathrm{t} / \mathrm{ha}$ & \\
\hline \multirow{3}{*}{$60 \mathrm{HST}$} & $20 \times 40$ & 9,40 & 9,73 & 9,73 & $9,62 \mathrm{a}$ \\
& $20 \times 50$ & 11,13 & 10,86 & 11,20 & $11,06 \mathrm{a}$ \\
& $20 \times 60$ & 11,2 & 10,80 & 11,00 & $11,00 \mathrm{a}$ \\
\cline { 2 - 5 } 74 HST & Rerata & $10,57 \mathrm{a}$ & $10,46 \mathrm{a}$ & $10,64 \mathrm{a}$ & $(-)$ \\
\hline \multirow{3}{*}{ H4 } & $20 \times 40$ & 8,4 & 9,06 & 7,6 & $8,35 \mathrm{a}$ \\
& $20 \times 50$ & 7,93 & 9,13 & 8,6 & $8,55 \mathrm{a}$ \\
& $20 \times 60$ & 8,46 & 5,33 & 7,33 & $7,04 \mathrm{a}$ \\
\hline
\end{tabular}

Keterangan: Angka pada kolom dan baris diikuti huruf sama menunjukkan tidak berbeda pada tingkat nyata $(\alpha) 5 \%$ menurut uji DMRT; (-): Tidak terjadi interaks antar faktor.

\subsection{Berat Polong Per Tanaman}

Hasil sidik ragam menunjukkan bahwa tidak terjadi interaksi antara perlakuan jarak tanam dengan takaran pupuk kandang pada pengamatan berat polong per tanaman setiap waktu pengamatan. Penggunaan jarak tanaman $20 \mathrm{~cm}$ x $60 \mathrm{~cm}$ menghasilkan berat polong per tanaman paling berat $(45,38 \mathrm{~g})$ dan berbeda nyata pada panen 60 HST, sedangkan pada panen 74 HST tidak berpengaruh nyata, tetapi berat polong per tanaman tertinggi dihasilkan pada penanaman dengan jarak tanam $20 \mathrm{~cm}$ x $50 \mathrm{~cm}(33,60 \mathrm{~g})$. Pengaruh utama perlakuan takaran pupuk kandang berpengaruh nyata terhadap berat polong per tanaman pada pengamatan 60 HST, sedangkan pada pengamatan 74 HST tidak berpengaruh nyata, tetapi berat polong per tanaman tertinggi terdapat pada petak yang diberikan pupuk dengan takaran $10 \mathrm{t} / \mathrm{ha}$.

\section{Tabel 11. Berat Polong Per Tanaman}

\begin{tabular}{cccccc}
\hline Waktu & Jarak & \multicolumn{3}{c}{ Takaran Pupuk Kandang } & \multirow{2}{*}{ Rerata } \\
\cline { 3 - 5 } & Tanam & $5 \mathrm{t} / \mathrm{ha}$ & $10 \mathrm{t} / \mathrm{ha}$ & $15 \mathrm{t} / \mathrm{ha}$ & \\
\hline \multirow{3}{*}{$60 \mathrm{HST}$} & $20 \times 40$ & 33.30 & 41.05 & 29.50 & $34.62 \mathrm{a}$ \\
& $20 \times 50$ & 44.01 & 38.86 & 36.30 & $39.72 \mathrm{a}$ \\
& $20 \times 60$ & 41.52 & 45.89 & 48.76 & $45.38 \mathrm{a}$ \\
\hline \multirow{3}{*}{$74 \mathrm{HST}$} & Rerata & $39.61 \mathrm{a}$ & $41.63 \mathrm{a}$ & $38.18 \mathrm{a}$ & $(-)$ \\
& $20 \times 40$ & 21.72 & 41.84 & 31.94 & $31.83 \mathrm{a}$ \\
& $20 \times 50$ & 31.90 & 35.20 & 33.70 & $33.60 \mathrm{a}$ \\
& $20 \times 60$ & 28.90 & 41.40 & 23.00 & $31.10 \mathrm{a}$ \\
\hline
\end{tabular}

Keterangan: Angka pada kolom dan baris diikuti huruf sama menunjukkan tidak berbeda pada tingkat nyata $(\alpha) 5 \%$ menurut uji DMRT; (-): Tidak terjadi interaksi antar faktor.

\subsection{Jumlah Polong Per Petak}

Hasil sidik ragam menunjukkan bahwa tidak terjadi interaksi antar perlakuan jarak tanam dengan takaran pupuk kandang terhadap jumlah polong per petak pada setiap waktu pengamatan. Perlakuan utama jarak tanam tidak berpengaruh nyata pada setiap waktu pengamatan, tetapi penanaman dengan jarak $20 \mathrm{~cm}$ x $50 \mathrm{~cm}$ menghasilkan jumlah polong per petak terbanyak. Perlakuan utama takaran pupuk kandang tidak berpengaruh nyata, tetapi petak yang diberi takaran 10 t/ha menghasilkan tanaman dengan jumlah polong per petak paling banyak pada setiap waktu pengamatan.

Tabel 12. Jumlah Polong Per Petak

\begin{tabular}{cccccc}
\hline \multirow{2}{*}{ Waktu Panen } & Jarak & \multicolumn{3}{c}{ Takaran Pupuk Kandang } & \multirow{2}{*}{ Rerata } \\
\cline { 3 - 5 } & Tanam & $5 \mathrm{t} / \mathrm{ha}$ & $10 \mathrm{t} / \mathrm{ha}$ & $15 \mathrm{t} / \mathrm{ha}$ & \\
\hline \multirow{3}{*}{$60 \mathrm{HST}$} & $20 \times 40$ & $503 \mathrm{a}$ & $502 \mathrm{a}$ & $487 \mathrm{~b}$ & $502 \mathrm{a}$ \\
& $20 \times 50$ & $445 \mathrm{c}$ & $435 \mathrm{c}$ & $448 \mathrm{c}$ & $442 \mathrm{~b}$ \\
& $20 \times 60$ & $336 \mathrm{~d}$ & $322 \mathrm{~d}$ & $333 \mathrm{~d}$ & $330 \mathrm{c}$ \\
\cline { 2 - 5 } & Rerata & $428 \mathrm{a}$ & $425 \mathrm{a}$ & $422 \mathrm{a}$ & $(+)$ \\
\hline \multirow{4}{*}{$74 \mathrm{HST}$} & $20 \times 40$ & $430 \mathrm{a}$ & $453 \mathrm{a}$ & $377 \mathrm{~b}$ & $420 \mathrm{a}$ \\
& $20 \times 50$ & $317 \mathrm{~d}$ & $365 \mathrm{~cd}$ & $352 \mathrm{~d}$ & $344 \mathrm{~b}$ \\
& $20 \times 60$ & $290 \mathrm{~cd}$ & $240 \mathrm{e}$ & $202 \mathrm{f}$ & $244 \mathrm{c}$ \\
\hline
\end{tabular}

Keterangan: Angka pada kolom dan baris diikuti huruf sama menunjukkan tidak berbeda pada tingkat nyata $(\alpha) 5 \%$ menurut uji DMRT; (-): Tidak terjadi interaksi antar faktor

\subsection{Berat Polong Per Petak}

Hasil sidik ragam menunjukkan bahwa tidak terjadi interaksi antar perlakuan jarak tanam dengan takaran pupuk kandang terhadap berat polong per petak pada setiap waktu pengamatan. Perlakuan jarak tanam berpengaruh nyata pada setiap waktu pengamatan, tetapi berat polong per petak tertinggi terjadi pada petak yang ditanami buncis dengan jarak $20 \mathrm{~cm}$ x $40 \mathrm{~cm}$. Perlakuan utama takaran pupuk kandang tidak berpengaruh nyata terhadap berat polong per petak pada setiap waktu panen. Pada pengamatan $60 \mathrm{HST}$, berat polong per petak tertinggi $(2,08 \mathrm{t} / \mathrm{ha})$ terdapat pada petak yang diberikan pupuk dengan takaran 5t/ha, sedangkan pada panen 74 HST berat polong per petak tertinggi $(1,72 \mathrm{t} / \mathrm{ha})$ terdapat pada petak yang diberikan pupuk dengan takaran 10 t/ha (Tabel 10.).

Tabel 13. Berat polong per petak (t/ha)

\begin{tabular}{cccccc}
\hline Waktu & Jarak & \multicolumn{3}{c}{ Takaran Pupuk Kandang } & \multirow{2}{*}{ Rerata } \\
\cline { 3 - 5 } Panen & Tanam & $5 \mathrm{t} / \mathrm{ha}$ & $10 \mathrm{t} / \mathrm{ha}$ & $15 \mathrm{t} / \mathrm{ha}$ & \\
\hline \multirow{3}{*}{$60 \mathrm{HST}$} & $20 \times 40$ & 2.45 & 2.53 & 2.37 & $2,45 \mathrm{a}$ \\
& $20 \times 50$ & 2.17 & 2.13 & 2.18 & $2,15 \mathrm{a}$ \\
& $20 \times 60$ & 1.64 & 1.57 & 1.61 & $1,60 \mathrm{a}$ \\
\cline { 2 - 5 } & Rerata & $2,08 \mathrm{a}$ & $2,07 \mathrm{a}$ & $2,05 \mathrm{a}$ & $(-)$ \\
\hline \multirow{3}{*}{$74 \mathrm{HST}$} & $20 \times 40$ & 2.09 & 2.21 & 1.84 & $2,04 \mathrm{a}$ \\
& $20 \times 50$ & 1.54 & 1.78 & 1.71 & $1,67 \mathrm{a}$ \\
& $20 \times 60$ & 1.42 & 1.18 & 0.99 & $1,19 \mathrm{a}$ \\
\hline
\end{tabular}

Keterangan: Angka pada kolom dan baris diikuti huruf sama menunjukkan tidak berbeda pada tingkat nyata $(\alpha) 5 \%$ menurut uji DMRT; (-): Tidak terjadi interaksi antar faktor.

\subsection{Indeks Panen}

Hasil sidik ragam menunjukkan bahwa takaran pupuk kandang dan jarak tanam 20 x $60 \mathrm{~cm}$ menghasilkan indeks panen paling tinggi yaitu $(35,21)$. yang tidak berbeda nyata dibanding perlakuan lainnya. Pengaruh utama perlakuan takaran pupuk kandang 15 t/ha menghasilkan indeks panen pada pengamatan 74 HST.

Tabel 14. Indeks Panen

\begin{tabular}{ccccc}
\hline Jarak & \multicolumn{3}{c}{ Takaran Pupuk Kandang } & \multirow{2}{*}{ Rerata } \\
\cline { 2 - 4 } Tanam & $5 \mathrm{t} / \mathrm{ha}$ & $10 \mathrm{t} / \mathrm{ha}$ & $15 \mathrm{t} / \mathrm{ha}$ & \\
\hline $20 \times 40$ & 45,34 & 53,23 & 28,66 & $29,88 \mathrm{a}$ \\
$20 \times 50$ & 35,20 & 35,66 & 41,57 & $27,84 \mathrm{a}$ \\
$20 \times 60$ & 31,29 & 39,48 & 35,2 & $35,21 \mathrm{a}$ \\
\hline Rerata & $28,28 \mathrm{a}$ & $29,18 \mathrm{a}$ & $30,17 \mathrm{a}$ & $(-)$ \\
\hline
\end{tabular}

Keterangan: Angka pada kolom dan baris diikuti huruf sama menunjukkan tidak berbeda pada tingkat nyata $(\alpha) 5 \%$ menurut uji DMRT; (-): Tidak terjadi interaksi antar faktor.

\subsection{Pembahasan}

Hasil penelitian menunjukkan bahwa suhu tanah terendah terdapat pada 45 HST dan 60 HST (Tabel 1.). Hal ini terjadi karena pada 45 HST dan 60 HST kanopi tanaman menutupi tanah sehingga suhu tanahnya rendah. Jarak tanam 20 $\mathrm{cm}$ x $40 \mathrm{~cm}$ memiliki kadar lengas tanah yang berada pada kisaran tidak tinggi dan tidak rendah (optimal) pada pengamatan 1 dan 60 HST, sedangkan pada pengamatan 45 HST kadar lengas tanahnya paling tinggi. Petak tanaman dengan perlakuan utama pemberian pupuk kandang sapi pada takaran $10 \mathrm{t} / \mathrm{ha}$ memiliki kadar lengas tanah lebih tinggi pada pengamatan 60 HST, sedangkan pada pengamatan 1 dan 45 HST nilainya berada pada kisaran yang optimal (Tabel 2.).

Pada perlakuan pemberian pupuk kandang sapi $10 \mathrm{t} / \mathrm{ha}$ menghasilkan tanaman dengan jumlah daun paling tinggi, sedangkan diameter batang tidak berbeda nyata. Hasil tanaman menunjukkan bahwa perlakuan jarak tanam $20 \mathrm{~cm}$ x $40 \mathrm{~cm}$ menghasilkan berat polong per petak tertinggi pada $60 \mathrm{HST}(2,45 \mathrm{t} / \mathrm{ha})$ dan panen 74 HST (2,04 t/ha) karena komponen hasil jumlah polong per petak paling banyak. Hal ini menunjukkan bahwa penanaman pada jarak tanam $20 \mathrm{~cm}$ x $40 \mathrm{~cm}$ sudah cukup meningkatkan hasil pada tanaman buncis (Andrianto \& Indrianto, 2004). 
Pemberian pupuk kandang 10 t/ha merupakan takaran yang cukup optimal untuk meningkatkan hasil tanaman buncis. Pemberian pupuk kandang sapi 10 t/ha sudah cukup meningkatkan hasil pada tanaman kacang buncis (Wiskandar, 2002; Pranata, 2010). Hasil penelitian Usboko $d k k$., (2017) juga menunjukkan bahwa penggunaan pupuk kandang babi dengann dosis 10-15 t/ha dapat meningkat pertumbuhan dan hasil berat polong segar tanaman buncis.

Interaksi antara perlakuan pada pengamatan komponen hasil jumlah polong per petak menunjukkan bahwa perlakuan penanaman dengan jarak $20 \mathrm{~cm}$ x $40 \mathrm{~cm}$ dengan pemberian takaran pupuk kandang $10 \mathrm{t} / \mathrm{ha}$ menghasilkan tanaman dengan jumlah polong per petak paling tinggi pada panen 60 HST (520 polong) dan 74 HST (453 polong), hal ini juga terjadi pada pengamatan berat polong per petak tertinggi yang dihasilkan dari kombinasi perlakuan yang sama, yaitu 2,53 t/ha pada panen $60 \mathrm{HST}$ dan 2,21 t/ha panen $74 \mathrm{HST}$.

\section{Simpulan}

Interaksi antara jarak tanam dan takaran pupuk kandang sapi terjadi pada parameter berat basah akar dan jumlah polong per petak setiap kali panen. Takaran pupuk kandang berpengaruh nyata pada parameter kadar lengas 60 HST dan polong buncis, sedangkan jarak tanam tidak berpengaruh nyata terhadap semua parameter. Perlakuan jarak tanam $20 \mathrm{~cm}$ x $40 \mathrm{~cm}$ dengan takaran pupuk $10 \mathrm{t} / \mathrm{ha}$ sudah cukup meningkatkan hasil tanaman buncis berat polong per petak (4,25 t/ha) lebih tinggi dibanding perlakuan lainnya.

\section{Pustaka}

Andrianto \& Indrianto, N. 2004. Budidaya Tanaman Buncis dan Analisis Tani. Yogyakarta: Absolut.

Cahyono, B. 2007. Kacang Buncis. Teknik Budidaya dan Analisis Usaha Tani. Yogyakarta: Kanisius.

Gomez, K.A. \& Gomez, A.A. 1984. Statistical Procedures for Agricultural Research. New York: John Wiley \& Sons.

Naimnule, M.A. 2016. Pengaruh Takaran Arang Sekam dan Pupuk Kandang Sapi terhadap Pertumbuhan dan Hasil Kacang Hijau (Vigna radiata L.). Savana Cendana, 1(04): 118-120.

Pranata, S.A. 2010. Meningkat Hasil Panen Dengan Pupuk Organik. Jakarta: AgroMedia Pustaka.

Rubatzky, V.E. \& Yamaguchi, M. 2012. World Vegetables: Principles, Production, and Nutritive Values. Berlin: Springer Science \& Business Media.

Usboko, A., Lelang, M.A. \& Neonbeni, E.Y. 2017. Pengaruh Jenis dan Dosis Pupuk Kandang terhadap Pertumbuhan dan Hasil Tanaman Kacang Buncis (Phaseolus vulgaris L.). Savana Cendana, 2(04): 62-64.

Winarno, L. \& Winarto, D.A. 1992. Pengaruh Pupuk Kandang Ayam dan Agrovit terhadap Pertumbuhan dan Produksi Tanaman Lombok. Jurnal Horti, 2(3): 19-20.

Wirakusumah, E.S. 1994. Buah dan Sayur untuk Terapi. Jakarta: Penebar Swadaya.

Wiskandar 2002. Pemanfaatan Pupuk Kandang untuk Memperbaiki Sifat Fisik Tanah di Lahan Kritis yang Telah Diteras. 